\title{
The biology and ecology of the liverwort Cephaloziella varians in Antarctica
}

\author{
K.K. NEWSHAM* \\ British Antarctic Survey, NERC, High Cross, Madingley Road, Cambridge CB3 OET, UK \\ *kne@bas.ac.uk
}

\begin{abstract}
The biology and ecology of Cephaloziella varians, the most widespread and abundant liverwort in Antarctica, are reviewed. A description of the species is given, together with information on its geographical distribution, reproduction, habitats, associated organisms and responses to environmental stresses. Characteristics of its photosynthetic physiology are also presented, including data on oxygen evolution rates and chlorophyll $a$ fluorescence parameters. Substratum and tissue chemistry, water relations and pigments are discussed, along with recent data demonstrating that the dark pigment in the apical leaves of C. varians is the anthocyanidin riccionidin A. Recent studies showing that the ericoid mycorrhizal symbiont Rhizoscyphus ericae is present in the tissues of the plant at a wide range of locations in the maritime and subAntarctic are also described. It is evident, from the literature reviewed, that $C$. varians has several adaptations that enable it to survive in the Antarctic biome, explaining its survival at higher latitudes than any other hepatic. The species' major adaptations include the synthesis of riccionidin A in apical leaves, enabling efficient heat absorption and protection from photoinhibition, and the presence in stems and rhizoids of fungal hyphae, which are potentially beneficial to the hepatic's nutrition and possibly also synthesize cryoprotectants.
\end{abstract}

Received 8 May 2009, accepted 27 August 2009

Key words: adaptation, anthocyanidin, cryoprotection, liverwort, mycorrhiza, riccionidin A

\section{Introduction}

Of the 27 species of liverwort that are known from Antarctica, only one, the leafy liverwort Cephaloziella varians (Gottsche) Steph., occurs in the continental Antarctic (Bednarek-Ochyra et al. 2000). This species, which is the commonest and most widespread liverwort in Antarctica, is the only hepatic to occur at latitudes above $70^{\circ} \mathrm{S}$. Only 22 native species of moss, and no higher plant species, have been recorded beyond this latitude (Ochyra et al. 2008). Terrestrial habitats beyond $70^{\circ} \mathrm{S}$ present some of the most hostile conditions for plant life on Earth, including very low winter temperatures, extended periods of ice- and snow-cover and darkness, extreme aridity, wide diurnal and annual variations in temperature and solar radiation exposure, and, in summer, frequent freeze-thaw cycles. However, despite the occurrence of $C$. varians in such extreme habitats, the reasons for its success in the Antarctic biome remain obscure.

This article has two aims. The first is to collate the available information from the literature on C. varians. A description of the hepatic and its reproduction is given, together with information on the habitats in which it occurs, its photosynthesis, pigments, water relations, responses to changing environmental conditions and its associated organisms. The second aim of the article is to attempt to identify the adaptations that have led to the success of C. varians in the Antarctic terrestrial biome.

The format of this paper is based upon that of the Biological Flora of the British Isles series published in
Journal of Ecology, initiated by the late Professor Arthur Willis of the University of Sheffield.

\section{Geographical distribution}

Cephaloziella varians occurs in the sub-, northern and southern maritime and continental Antarctic (Fig. 1a). Geographical definitions of each of these four regions are given in Table I. The species is widespread throughout the sub- and maritime Antarctic, occurring at Heard Island, South Georgia, Bouvetøya and the South Sandwich, South Orkney and South Shetland islands, and along the western Antarctic Peninsula to the eastern coast of Alexander Island (Fig. 1a \& b). It is the only hepatic known from continental Antarctica, where it occurs at coastal locations in Victoria, Wilkes, Princess Elizabeth and Mac Robertson lands (Fig. 1a). Its southernmost known location is at $77^{\circ} \mathrm{S}$, at Granite Harbour in Botany Bay, Victoria Land (Seppelt \& Green 1998). The species usually occurs within $2 \mathrm{~km}$ of the coast and at low $(<350 \mathrm{~m})$ altitudes, although it is present on Mount Melbourne in the continental Antarctic on heated ground at an altitude of $2700 \mathrm{~m}$ (Smith 2007). For the precise locations of C. varians collections from the Antarctic, see Ochyra \& Ván̆a (1989a, 1989b) and Bednarek-Ochyra et al. (2000).

Outside Antarctica, C. varians is present in mountainous regions, including the Alps, Pyrenees and Carpathians ranges, and in New Zealand, Alaska, Canada, Greenland, Sweden, Iceland and the Russian Arctic (Schuster \& Damsholt 1974, Schljakov 1979, Söderström 1995, Konstantinova \& Potemkin 

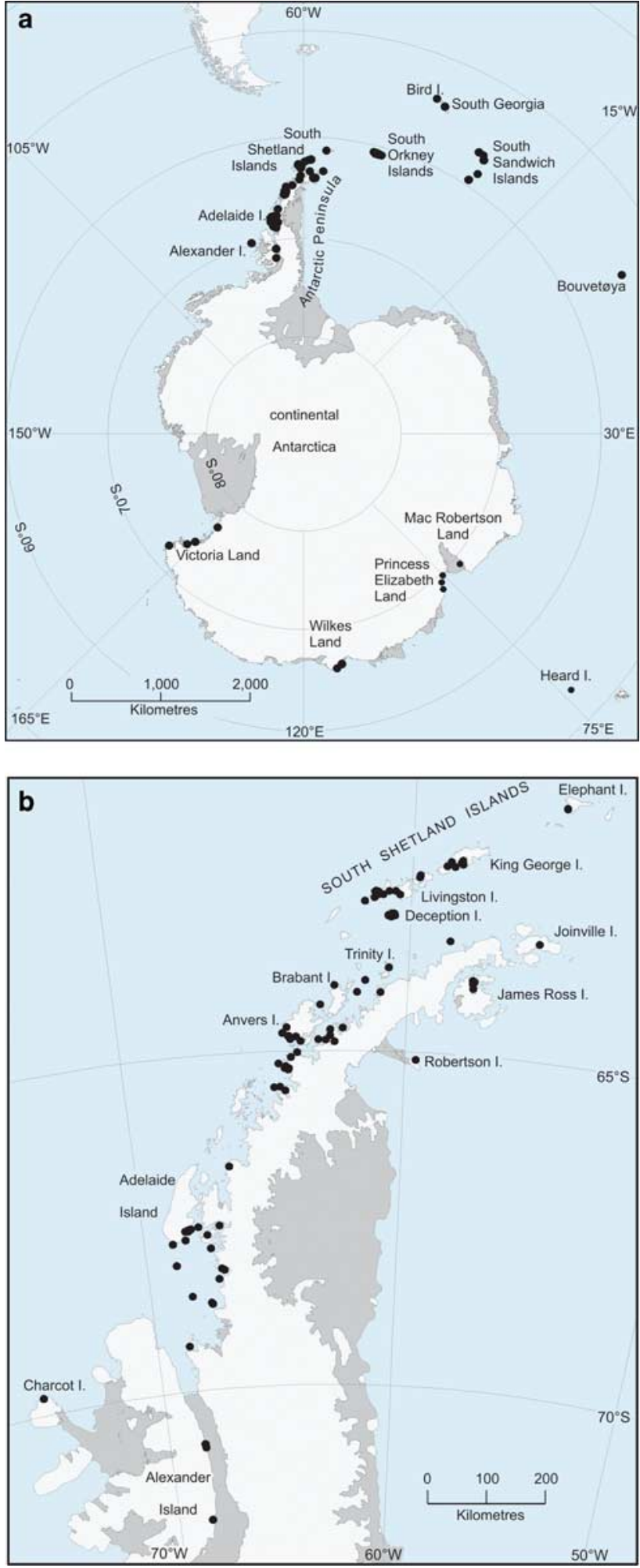

Fig. 1. The distribution of Cephaloziella varians in a. sub-, maritime and continental Antarctica, and b. the South Shetland Islands and Antarctic Peninsula. Data from the Antarctic Plant Database (http://www.antarctica.ac.uk/ Resources/BSD/PlantDatabase/) and Bednarek-Ochyra et al. (2000).
1996, Bednarek-Ochyra et al. 2000). It is frequently recorded in the Arctic as C. arctica, which is considered to be synonymous with $C$. varians (Ochyra \& Váňa 1989a). In agreement with this, Ochyra \& Váňa (1989b) note that C. varians, together with four other Antarctic hepatics (Anthelia juratzkana (Limpr.) Trevis., Barbilophozia hatcheri (Evans) Loeske, Lophozia excisa (Dicks.) Dumort. and Scapania obcordata (Berggr.) Arnell), belongs to a bipolar floristic element. They note that these taxa may have attained their southern range by long-range dispersal, rather than by fragmentation of their original ranges.

\section{Species description}

A detailed description of the species is given by BednarekOchyra et al. (2000), from which much of the following is derived. Plants very small and delicate, with stems 2-8 (-12) $\mathrm{mm}$ in length, usually creeping or semi-erect and sparsely or lateral-intercalary branched. Leaves $100-250 \mu \mathrm{m}$ in length, plane or concave, barely overlapping, typically $1.5-2$ times as wide as the stem, transversely or subtransversely inserted, distinctively bilobed to $0.5-0.7$ of length (Fig. $2 \mathrm{a} \& \mathrm{~b}$ ). Lobes ovate to ovate-triangular, erect or incurved and 6-10 cells wide at their base. Leaf cell dimensions $c .12-15 \times 10-13 \mu \mathrm{m}$. Leaves and stems smooth. Rhizoids hyaline, typically occurring at base of stem. Oil bodies frequent in cells (Post \& Vesk 1992).

Leaves and stems slightly lustrous, especially in damp locations, and exceptionally variable in colour, ranging from deep violet to black, brown-green, green and yellowgreen (Seppelt \& Green 1998, Bednarek-Ochyra et al. 2000, Newsham et al. 2005). Considerable variation in pigmentation can occur within a given location: sun-exposed plants are deeply-pigmented (Fig. 2a), but plants growing in shaded habitats are uniformly green (Fig. 2b). Observations suggest that deeply-pigmented plants in the maritime Antarctic typically occur in unshaded habitats at the southern end of the species' range (Bednarek-Ochyra et al. 2000, Newsham et al. 2005), possibly reflecting the more continental climate in this region, which is typified by extended periods of cloudless skies during summer (see Effects of solar radiation, below).

\section{Reproduction}

Autoecious or pseudodioecious. Male inflorescence terminal, becoming intercalary, bracts imbricate, monandrous and saccate at base, in 4-10 pairs. Female inflorescences on elongated shoots, bracts broadly ovate, and bracteoles, which are smaller than bracts, mostly bilobed. Perianths obloid to obloid-clavate, formed by thick-walled rectangular cells in the apical region. Capsule ovoid-elliptical, rounded at apices with bistratose walls. Epidermal cells of capsule with nodular thickenings and inner cells with semi-annular narrow bands. Spores $9-12 \mu \mathrm{m}$ in diameter, delicately verruculose (Bednarek-Ochyra et al. 2000, Smith \& Convey 2002). 
Table I. Regions of Antarctica in which C. varians occurs and their climates. Adapted from Smith (1984).

\begin{tabular}{|c|c|c|}
\hline Region & Localities & Climate \\
\hline sub-Antarctic & South Georgia, Bird and Heard islands & $\begin{array}{l}\text { cool oceanic climate, annual mean air temperature }>0{ }^{\circ} \mathrm{C} \text {, mean monthly air } \\
\text { temperatures }>0^{\circ} \mathrm{C} \text { for at least six months, coldest monthly mean air } \\
\text { temperature rarely }<-2^{\circ} \mathrm{C} \text {, precipitation }>900 \mathrm{~mm} \text { per annum }\end{array}$ \\
\hline northern maritime & Bouvetøya, South Sandwich, South Orkney and & cold moist maritime climate, mean monthly air temperature $>0^{\circ} \mathrm{C}$ for \\
\hline Antarctic & $\begin{array}{l}\text { South Shetland islands, western Antarctic } \\
\text { Peninsula and offshore islands to } 66^{\circ} \mathrm{S}\end{array}$ & $\begin{array}{l}3-4 \text { months, rarely }<-10^{\circ} \mathrm{C} \text { in winter, precipitation } 350-500 \mathrm{~mm} \text { per annum, } \\
\text { with much falling as rain during summer }\end{array}$ \\
\hline southern maritime & western Antarctic Peninsula and offshore islands & cold dry maritime climate, mean monthly air temperature $>0^{\circ} \mathrm{C}$ for \\
\hline Antarctic & $\begin{array}{l}\text { from } 66^{\circ} \mathrm{S} \text { to } 72^{\circ} \mathrm{S} \text { and north-east coast of } \\
\text { Peninsula to } 63^{\circ} \mathrm{S}\end{array}$ & $\begin{array}{l}1-2 \text { months, rarely }<-15^{\circ} \mathrm{C} \text { in winter, precipitation }<350 \mathrm{~mm} \text { per annum, } \\
\text { with only occasional rain }\end{array}$ \\
\hline $\begin{array}{l}\text { coastal continental } \\
\text { Antarctic }\end{array}$ & coastal regions of Greater Antarctica & $\begin{array}{l}\text { cold, arid climate with mean monthly air temperatures }>0{ }^{\circ} \mathrm{C} \text { for } 0-1 \\
\text { months, winter mean air temperature of between }-5 \text { and }-25^{\circ} \mathrm{C} \text {, precipitation } \\
100-150 \mathrm{~mm} \text {, but rain very rare }\end{array}$ \\
\hline
\end{tabular}

Elaters free, bispiral and 7-8 $\mu \mathrm{m}$ in diameter. Gemmae twocelled, $15-25 \mu \mathrm{m}$ in length, $10-15 \mu \mathrm{m}$ in width (Fig. 2a, inset), borne on the margins of leaves and formed frequently in the natural environment. Vegetative reproduction also by branch fragmentation (Seppelt \& Green 1998).

Although the species is almost entirely sterile in the Antarctic natural environment, sporophytes have been observed in populations on the South Shetland Islands, in the Marguerite Bay region and on Alexander Island in the southern maritime Antarctic since the mid 1990s, possibly as a consequence of climate warming in the maritime Antarctic (Smith \& Convey 2002). Mean spore counts per capsule from these locations are 23750 and 14000 , respectively. Sporophytes are also occasionally found on plants in geothermally-heated habitats in the South Sandwich Islands (Convey et al. 2000).

Chromosomes $n=18(16+2 \mathrm{~m})$, based on material from South Georgia and King George Island (Newton 1980, Ochyra et al. 1982). The smallest of the nine pairs of

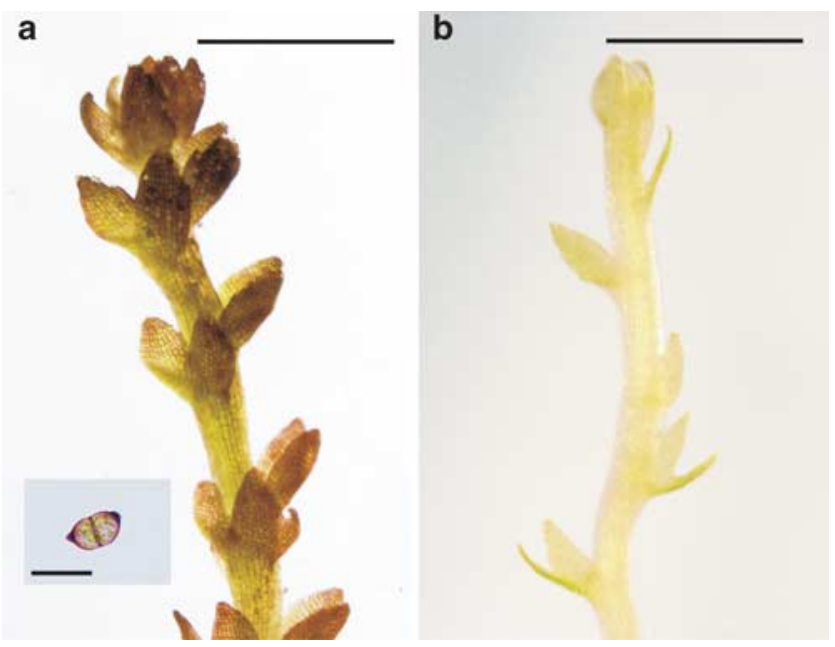

Fig. 2. Micrographs of a. sun-exposed, and b. shade-adapted forms of Cephaloziella varians. Bars are $500 \mu \mathrm{m}$. Inset in a. is a gemma. Bar in inset is $25 \mu \mathrm{m}$. Material collected from Léonie Island, Ryder Bay, south-western Antarctic Peninsula. chromosomes are unique in being composed of two unequal m-chromosomes (Newton 1980).

\section{History}

Cephaloziella varians was originally described as Jungermannia varians by Gottsche (1890) from material collected by H. Will at South Georgia during the German Polar Year Expedition in 1882-83. It was later assigned to Cephalozia varians by Stephani (1901), based on material from the Gerlache Strait collected by E. Racovitza of the Belgian Antarctic Expedition in 1897-99. Stephani (1905) subsequently assigned the species to Cephaloziella varians.

\section{Taxonomic placement}

There is considerable phenotypic plasticity between populations of C. varians from different locations in the Antarctic, which has led to the elevation of several different names for the taxon from the biome (e.g. Grolle 1972,

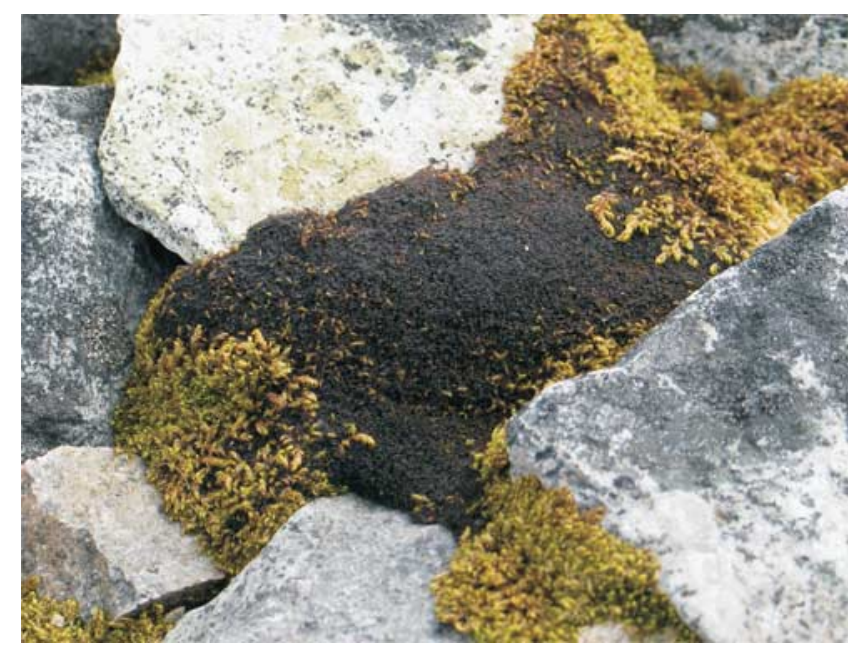

Fig. 3. A darkly pigmented colony of sun-exposed Cephaloziella varians growing amongst shoots of the moss Sanionia uncinata at Rothera Point on Adelaide Island. The colony is $c .100 \mathrm{~mm}$ in width. 
Table II. pH and organic matter content of substrata on which C. varians occurs at a range of maritime and sub-Antarctic locations. Data are means of $5-8$ replicates \pm SD.

\begin{tabular}{lccc}
\hline Location & Latitude and longitude & pH $\left(\mathrm{H}_{2} \mathrm{O}\right)$ & ${\text { organic matter }(\%)^{1}}^{1}$ \\
\hline Schlieper Bay, South Georgia & $54^{\circ} 00^{\prime} \mathrm{S}, 38^{\circ} 04^{\prime} \mathrm{W}$ & $4.917 \pm 0.387$ & $94.39 \pm 0.78$ \\
Foca Point, Signy Island $^{2}$ & $60^{\circ} 42^{\prime} \mathrm{S}, 45^{\circ} 39^{\prime} \mathrm{W}$ & $5.866 \pm 0.398$ & $90.05 \pm 2.40$ \\
Factory Bluffs, Signy Island $^{2}$ & $60^{\circ} 43^{\prime} \mathrm{S}, 45^{\circ} 36^{\prime} \mathrm{W}$ & $5.046 \pm 0.154$ & $93.59 \pm 1.59$ \\
Rothera Point, Adelaide Island & $67^{\circ} 34^{\prime} \mathrm{S}, 68^{\circ} 07^{\prime} \mathrm{W}$ & $5.346 \pm 0.098$ & $94.73 \pm 0.66$ \\
Ablation Valley, Alexander Island & $70^{\circ} 55^{\prime} \mathrm{S}, 68^{\circ} 20^{\prime} \mathrm{W}$ & $6.467 \pm 0.218$ & $34.49 \pm 9.21$ \\
Moutonnée Valley, Alexander Island & $70^{\circ} 55^{\prime} \mathrm{S}, 68^{\circ} 20^{\prime} \mathrm{W}$ & $6.880 \pm 0.085$ & $23.68 \pm 5.93$ \\
\hline
\end{tabular}

${ }^{1} 550^{\circ} \mathrm{C}$ for $2 \mathrm{~h},{ }^{2}$ South Orkney Islands

Schuster \& Damsholt 1974, Fulford 1976, Schuster 1980). The species has frequently been referred to in the literature as Cephaloziella exiliflora (Tayl.) Steph. (e.g. Seppelt 1983, Williams et al. 1994, Seppelt \& Green 1998), but it is now accepted that all Antarctic Cephaloziella should be referred to C. varians, with $C$. exiliflora, a distinct species with larger leaves, vestigial underleaves and red-brown pigmentation, being restricted to Australasia (Ochyra \& Váňa 1989a, Bednarek-Ochyra et al. 2000).

Nucleotide sequence data for a specimen of $C$. varians from New Zealand are deposited in GenBank under accession numbers AY608222, DQ439689, AY608074 and AY607953 (Davis 2004, Forrest et al. 2006). These nucleotide sequences are of 26S large subunit ribosomal RNA, the ribulose biphosphate carboxylase $(r b c \mathrm{~L})$, small ribosomal protein (rps4) and the CD122 photosystem II $32 \mathrm{kDa}$ protein (psbA) genes, respectively. Based on these data, Forrest et al. (2006) place $C$. varians in a clade of leafy liverworts including C. hirta Schuster and species of Cephalozia, Stenorrhipis, Scapania, Diplophyllum, Tritomaria, Anastrophyllum, Tetralophozia, Herzogobryum, Nowellia, Schiffneria, Odontoschisma and Adelanthus.

\section{Microhabitat}

\section{Substratum}

Cephaloziella varians forms dense compact mats (Fig. 3), often of a few square metres in area, on the surface of moribund mosses, or more usually intertwined with the shoots of other bryophytes. The species occurs predominantly in moist to wet habitats, normally on acidic substrata with $\mathrm{pH}$ values of 4.9-6.9 (Table II). Davis (1986), Wynn-Williams (1988) and Smith (1990) similarly report $\mathrm{pH}$ values of 4.8-5.1 for mixed bryophyte communities in which $C$. varians occurs on Signy Island in the South Orkney Islands, at Rothera Point on Adelaide Island and on Bailey Peninsula in Wilkes Land, continental Antarctica. However, the species also occurs on more alkaline soils, such as those derived from marble on Signy Island, with $\mathrm{pH}$ values of up to 8.2 (Smith 1972). The substrata on which $C$. varians occurs are variable in their organic matter content, with between $24 \%$ and $95 \%$ loss on ignition (LOI) for material from Bird Island to Moutonnée Valley on Alexander Island, with more mineral substrata being encountered at more southerly locations (Table II). Roser et al. (1992) and Melick \& Seppelt (1992) report $95 \%$ and $88 \%$ LOI for the substratum under C. varians from Bailey Peninsula, whilst Wynn-Williams (1988) reports $91 \%$ and $87 \%$ LOI for peat under C. varians at Signy and Adelaide Islands, respectively. LOI values of between 3.3\% and 96.4\% are reported by Smith (1972) for soils on which $C$. varians occurs at Signy Island. Cephaloziella varians is also present on geothermallyheated ground, where soil surface temperatures reach $25-35^{\circ} \mathrm{C}$, on Mount Melbourne in Victoria Land, on Deception Island, and on Leskov, Visokoi, Candlemas

Table III. Extractable elements (mg $100 \mathrm{~g}^{-1}$ dry weight) in substrata on which C. varians occurs. Data for Factory Bluffs and the Bailey Peninsula are means of 5-7 replicates $\pm \mathrm{SD}$. Other data are single measurements.

\begin{tabular}{|c|c|c|c|c|c|c|c|c|}
\hline \multirow[t]{2}{*}{ Location } & \multirow[t]{2}{*}{ Latitude and longitude } & \multicolumn{7}{|c|}{ Element } \\
\hline & & $\mathrm{Na}$ & $\mathrm{K}$ & $\mathrm{Ca}$ & $\mathrm{Mg}$ & $\mathrm{P}$ & $\mathrm{NO}_{3}-\mathrm{N}$ & $\mathrm{NH}_{4}-\mathrm{N}$ \\
\hline Factory Bluffs, Signy Island ${ }^{1}$ & $60^{\circ} 43^{\prime} \mathrm{S}, 45^{\circ} 36^{\prime} \mathrm{W}$ & $16 \pm 14$ & $10 \pm 6$ & $30 \pm 24$ & $19 \pm 14$ & $10 \pm 1$ & $2.0 \pm 3.7$ & $1 \pm 1$ \\
\hline Gourlay Peninsula, Signy Island ${ }^{1}$ & $60^{\circ} 44^{\prime} \mathrm{S}, 45^{\circ} 35^{\prime} \mathrm{W}$ & - & 23 & 60 & - & 20 & 0.5 & 61 \\
\hline Cape Tuxen ${ }^{2}$ & $65^{\circ} 16^{\prime} \mathrm{S}, 64^{\circ} 08^{\prime} \mathrm{W}$ & 32 & 38 & 100 & 100 & 13 & $<0.1$ & 24 \\
\hline Bailey Peninsula, Wilkes Land & $66^{\circ} 17^{\prime} \mathrm{S}, 100^{\circ} 32^{\prime} \mathrm{E}$ & $19 \pm 7$ & $20 \pm 9$ & $123 \pm 48$ & $80 \pm 38$ & $21 \pm 21$ & $0.11 \pm 0.11$ & $6 \pm 5$ \\
\hline Rothera Point, Adelaide Island & $67^{\circ} 34^{\prime} \mathrm{S}, 68^{\circ} 07^{\prime} \mathrm{W}$ & 50 & 120 & 220 & 180 & 9.5 & 2.3 & 53 \\
\hline Refuge Islands (largest) ${ }^{2}$ & $68^{\circ} 21^{\prime} \mathrm{S}, 67^{\circ} 10^{\prime} \mathrm{W}$ & 27 & 44 & 180 & 60 & 12 & $<0.1$ & 52 \\
\hline
\end{tabular}

Data, which were all analysed by the same analytical chemistry facility, are from Holdgate et al. (1967), Wynn-Williams (1988) and Smith (1990, 1996). ${ }^{1}$ South Orkney Islands. ${ }^{2}$ Sites for which soil chemical data are reported by Smith (1996) for Polytrichum strictum, Sanionia uncinata and Bryum pseudotriquetrum/ Brachythecium austrosalebrosum, but at which C. varians also occurs (R.I.L. Smith, personal communication 2009). Dashes indicate missing data. 


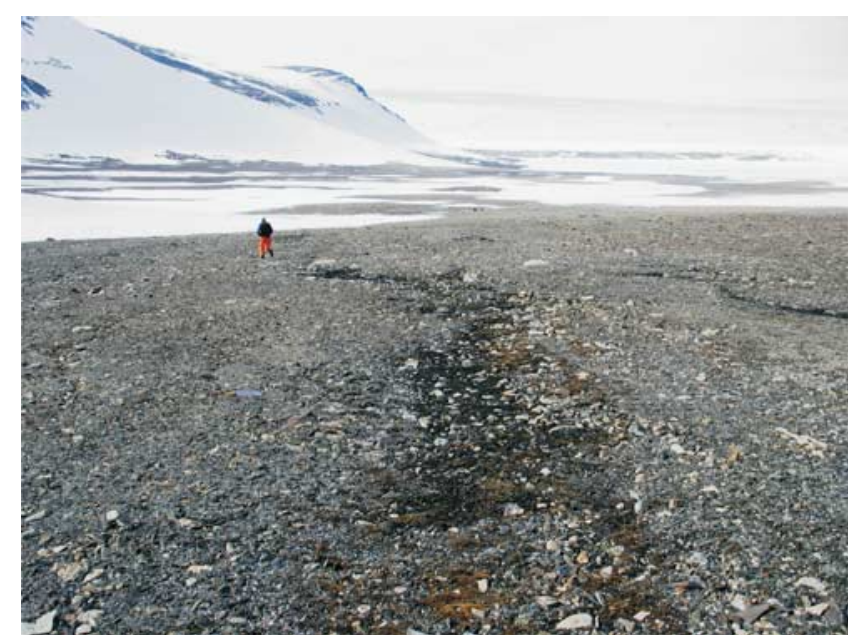

Fig. 4. Cephaloziella varians growing in meltwater channels with mixed mosses on the north-facing slopes of Moutonnée Valley on Alexander Island $\left(71^{\circ} \mathrm{S}\right)$, close to the southernmost limit of the species' range in the maritime Antarctic.

and Bellingshausen islands in the South Sandwich Islands (Longton \& Holdgate 1979, Broady et al. 1987, Convey et al. 2000, Smith 2005, Convey \& Smith 2006).

Concentrations of extractable elements in substrata on which C. varians occurs are highly variable (Table III), and, in broad terms, not limiting for plant growth (Allen 1989). For the nine locations for which data are available, moderate to high concentrations of sodium, potassium, calcium, magnesium, phosphorus and ammonium have been recorded in soil on which the species occurs (Table

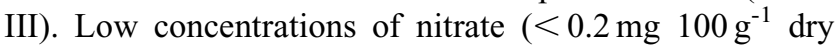
weight; Allen 1989) have been recorded in soil at five of the nine locations for which data are available (Table III).

\section{Topography}

Cephaloziella varians usually occurs on level or gentlysloping ground, commonly along rills, meltwater flushes, seepage channels and in sheltered depressions that are irrigated with meltwater during summer (Smith 1990, Bednarek-Ochyra et al. 2000). It often occurs on northfacing slopes, which are exposed to more solar radiation than south-facing areas, and where meltwater channels are more frequent (Fig. 4). The species is also found in drier habitats, such as on rock ledges or in crevices and fissures.

\section{Climate and plant temperature}

Cephaloziella varians occurs in a wide range of Antarctic habitats, in which mean monthly air temperature can exceed freezing point for several months each year, but can fall to $-25^{\circ} \mathrm{C}$ or below in winter (Table I). Precipitation in these environments varies widely between $c .100 \mathrm{~mm}$ and $>900 \mathrm{~mm}$ water equivalent per annum (Table I). Rainfall, particularly at more southerly latitudes, can be very rare,

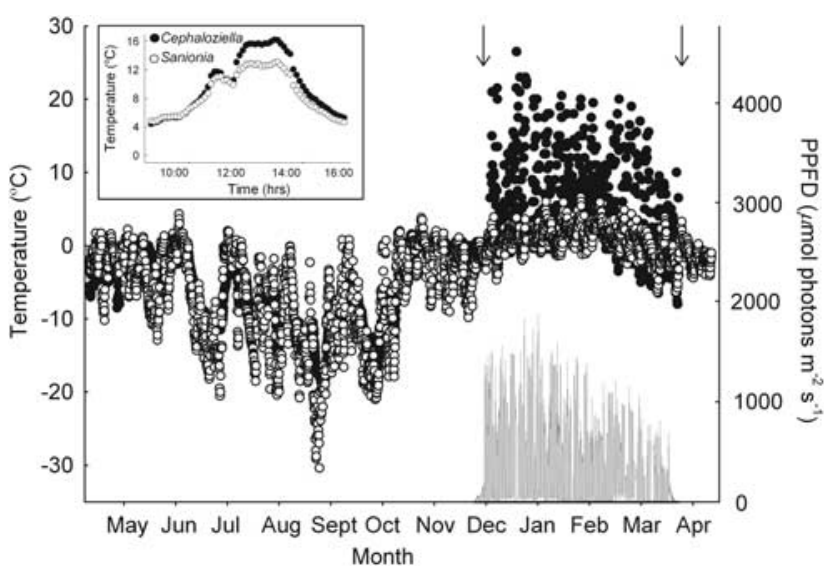

Fig. 5. Temperature of (•) sun-exposed Cephaloziella varians and $(O)$ air (left axis) and $(-)$ photosynthetic photon flux density (PPFD; right axis) between May 2006 and April 2007 at Rothera Point on Adelaide Island. Data were recorded every $3 \mathrm{~h}$. Plant temperature was measured by button loggers (SL51 Smart Button Logger, Status Instruments, Tewkesbury, UK) inserted into mats and air temperature was measured in the shade by two platinum resistance thermometers (PT100; Labfacility Ltd., Teddington, UK). PPFD was measured with a Skye SKP 215 sensor (Skye Instruments Ltd., Llandrindod Wells, UK). Arrows mark the period when plants were free from snow and ice. Inset shows temperatures of sun-exposed C. varians and the moss Sanionia uncinata at Rothera Point between $09 \mathrm{~h} 00$ and $16 \mathrm{~h} 00$ on 27 November 1999. The two colonies were separated by $c .0 .2 \mathrm{~m}$.

with any precipitation usually falling as snow. The temperature within a mat of $C$. varians varies widely, and often on a diurnal basis: at Rothera Point in the southern maritime Antarctic, mat temperature can reach $27^{\circ} \mathrm{C}$ at solar noon during the summer, and often exceeds air temperature by $20^{\circ} \mathrm{C}$, but frequently falls to below freezing point at night (Fig. 5). After the first snowfalls of autumn, mat temperature declines to near freezing point, closely tracking air temperature, and can fall to $-30^{\circ} \mathrm{C}$ during winter (Fig. 5). The high temperatures attained by sun-exposed shoots during the summer relative to air temperature are apparently due to their purple-black pigmentation, which enables efficient heat absorption: under clear skies, the temperature of $C$. varians mats can be up to $4^{\circ} \mathrm{C}$ higher than that of nearby Sanionia uncinata (Hedw.) Loeske shoots (Fig. 5, inset), which are light green in colour (Fig. 3).

\section{Light environment}

Cephaloziella varians experiences wide fluctuations in its light environment in the Antarctic. At Signy Island, the length of the growing season, when plants are not covered by snow and ice, is approximately six months (WynnWilliams 1980), whereas at a more southerly site, Rothera Point, the season rarely lasts for more than four months. Plants at the latter site become covered with snow and ice 


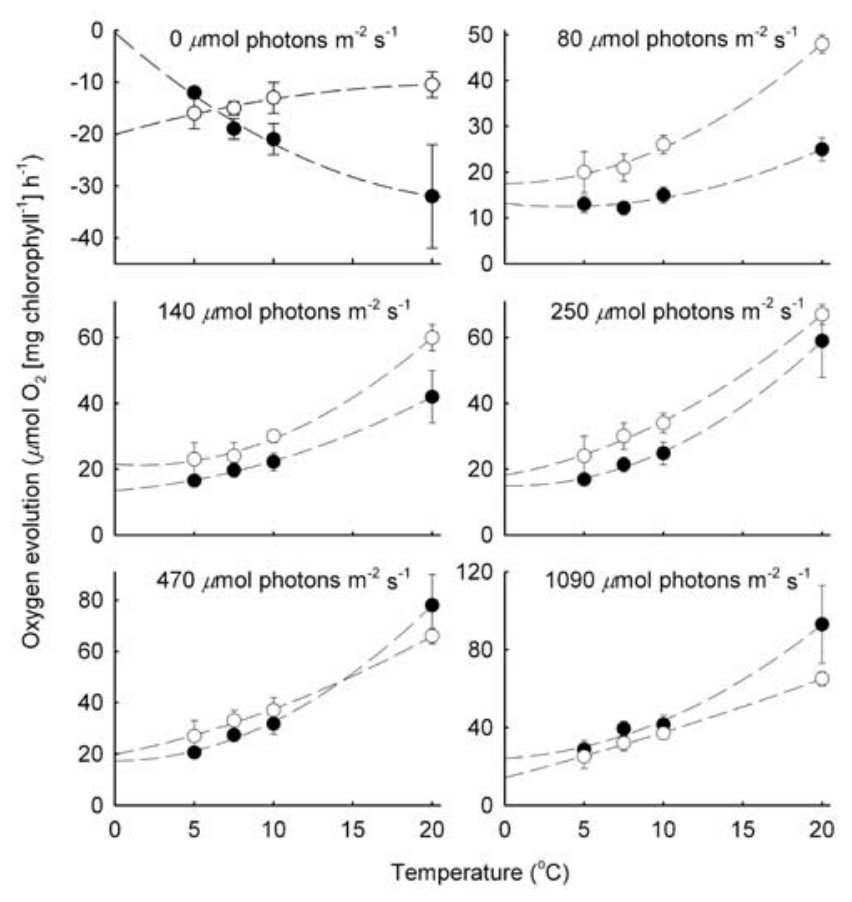

Fig. 6. Oxygen evolution of $(\bullet)$ sun-exposed and $(O)$ shadeadapted forms of Cephaloziella varians as a function of temperature at irradiances of $0,80,140,250,470$ and $1090 \mu \mathrm{mol}$ photons $\mathrm{m}^{-2} \mathrm{~s}^{-1}$. Data for $20^{\circ} \mathrm{C}$ are means of measurements for December and February from Post \& Vesk (1992). All other data are from Snell et al. (2009). Bars are S.E.M.

in the autumn, with photosynthetic photon flux density (PPFD) incident on the mats falling to close to zero when the depth of snow over them exceeds $c .200 \mathrm{~mm}$. This depth of snow is usually maintained for approximately eight months. Mild spells, when air temperatures can reach freezing point, do occur during winter (Fig. 5), but mats usually remain covered with snow and ice. In contrast, after snowmelt has occurred during the late spring, PPFD often reaches $1500 \mu \mathrm{mol}$ photons $\mathrm{m}^{-2} \mathrm{~s}^{-1}$ at solar noon (Fig. 5), and plants are exposed to almost continual daylight. However, low solar elevation angles during the early hours of the morning in the summer cause PPFD to fall to 20-40 $\mu \mathrm{mol}$ photons $\mathrm{m}^{-2} \mathrm{~s}^{-1}$ (Snell et al. 2007).

The exposure of plants to UV-B radiation $(280-315 \mathrm{~nm})$ can also vary widely, both as a consequence of changes in solar elevation angles and, in recent decades, anthropogenic depletion of ozone in the stratosphere. The daily mean biologically effective dose of UV-B radiation in the southern maritime Antarctic during late spring and early summer, when plants emerge from melting snow and ice, is c. $3 \mathrm{~kJ} \mathrm{~m}^{-2}$ under undepleted ozone columns (c. 350 Dobson Units, DU). However, when depletion of the gas occurs in the stratosphere to $200 \mathrm{DU}$, the daily dose of biologically effective UV-B radiation to which plants are exposed can reach $10.3 \mathrm{~kJ} \mathrm{~m}^{-2}$ (Newsham et al. 2002), which is three fold higher than the mean dose of UV-B received by plants in the region in midsummer, when ozone depletion does not occur. Cephaloziella varians is able to respond rapidly to these changes in UV-B exposure (see effects of solar radiation, below).

\section{Photosynthesis, fluorescence measurements and net primary production}

For $C$. varians growing in situ, the maximum quantum yield of photochemistry $\left(F_{\mathrm{v}} / F_{\mathrm{m}}\right)$ is $0.4-0.6$ (Snell et al. 2007, 2009), although values of this parameter can fall to $0.1-0.2$ (Newsham et al. 2002). Given that $F_{\mathrm{v}} / F_{\mathrm{m}}$ values are typically $0.7-0.8$ for most plant species growing under optimal conditions, the low values of this parameter indicate that C. varians is probably under constant physiological stress in the natural environment. Non-photosynthetic quenching $(q N)$, derived from fluorescence measurements, is $0.02-0.05$ for the sun-exposed form of $C$. varians but 0.17 for the shade form of the species, which is attributable to increased heat dissipation from chloroplasts in cells lacking dark pigmentation (Snell et al. 2009).

The shade-adapted and sun-exposed forms of $C$. varians also display different gas exchange characteristics. At low irradiances $\left(80-250 \mu \mathrm{mol}\right.$ photons $\left.\mathrm{m}^{-2} \mathrm{~s}^{-1}\right)$, the shade form of the species evolves significantly $(P<0.05)$ more oxygen than the sun-exposed form at temperatures of between $5^{\circ} \mathrm{C}$ and $20^{\circ} \mathrm{C}$ (Fig. 6). In contrast, at a temperature of $20^{\circ} \mathrm{C}$ and at higher irradiances $\left(470-1090 \mu \mathrm{mol}\right.$ photons $\left.\mathrm{m}^{-2} \mathrm{~s}^{-1}\right)$, the sun-exposed form evolves significantly $(P<0.05)$ more oxygen than the shade form (Fig. 6). Oxygen evolution of the shade form saturates at PPFD of 200-400 $\mu$ mol photons $\mathrm{m}^{-2} \mathrm{~s}^{-1}$, whereas that of the sun-exposed form apparently does not saturate at $<1090 \mu \mathrm{mol}$ photons $\mathrm{m}^{-2} \mathrm{~s}^{-1}$ (Post \& Vesk 1992, Snell et al. 2009). Gas exchange of $C$. varians is closely and positively associated with temperature, with sun-exposed and shade forms evolving up to 93 and $65 \mu \mathrm{mol} \mathrm{O}_{2}$ (mg chlorophyll ${ }^{-1}$ ) $\mathrm{h}^{-1}$ at $20^{\circ} \mathrm{C}$, respectively (Fig. 6). At present, the reduction in the dark respiration rate of sun-exposed $C$. varians at higher temperatures, and the lower dark respiration rate at $7.5-20^{\circ} \mathrm{C}$ of sun-exposed, compared with shade-adapted plants (Fig. 6), remain anomalous.

Davis (1981) gives estimates of net primary production for C. varians of between 58 and $98 \mathrm{~g}$ dry weight $\mathrm{m}^{-2} \mathrm{yr}^{-1}$ on Signy Island. However, these data should be regarded as approximations, as they are not based on empirical measurements.

\section{Chloroplast ultrastructure}

The chloroplasts of $C$. varians are spherical to slightly oval, and show little variation between different parts of the plant in size, shape or thylakoid content. Chloroplasts show marked differences between sun-exposed and shade-adapted forms of 
the species: in those of the former plants, the thylakoid system consists of sparsely-arranged elongated grana, usually comprising two or three thylakoids distributed evenly throughout the stroma. In those of shade-adapted plants, the thylakoid system is more extensive, with grana consisting of usually more than eight thylakoids (Post \& Vesk 1992). Thylakoids occupy $19 \%$ and $39 \%$ of the total chloroplast volume in sun-exposed and shaded plants, respectively (Post \& Vesk 1992).

\section{Pigments}

\section{Chlorophylls}

Roser et al. (1992) report a chlorophyll a concentration of $0.29 \mathrm{mg} \mathrm{g}^{-1}$ (fresh weight) in tissues of $C$. varians sampled from the Bailey Peninsula in Wilkes Land. Post \& Vesk (1992) similarly report total chlorophyll ( $a$ and $b$ ) concentrations of 0.21 and $0.38 \mathrm{mgg}^{-1}$ (fresh weight) respectively in the sunexposed and shade-adapted forms of $C$. varians from the Clarke Peninsula, also in Wilkes Land. Similar values of 0.20 and $0.33 \mathrm{mg}$ total chlorophyll $\mathrm{g}^{-1}$ (fresh weight) have been measured in sun-exposed and shade-adapted plants at Léonie Island in Ryder Bay, south-western Antarctic Peninsula, respectively (K.K. Newsham, unpublished data). Total chlorophyll concentrations in $C$. varians from Rothera Point of $1.2-3.3 \mathrm{mg} \mathrm{g}^{-1}$ (dry weight) are also reported by Newsham et al. (2005) and Snell et al. (2007, 2009). The chlorophyll $a / b$ ratios of plants from sun-exposed and shaded habitats, which vary between 2.1 and 2.4, do not differ (Post \& Vesk 1992, Snell et al. 2007).

\section{Carotenoids}

The concentration of total carotenoids in $C$. varians tissues typically varies between 0.15 and $0.45 \mathrm{mg} \mathrm{g}^{-1}$ (dry weight) (Newsham et al. 2002, Snell et al. 2007, 2009), with increased concentrations of carotenoids in plants exposed to high levels of solar radiation (see Effects of solar radiation, below). HPLC analyses indicate that lutein is the most abundant carotenoid in the tissues of $C$. varians, forming $76 \%$ of the total mass of carotenoids (Newsham et al. 2002). Neoxanthin, zeaxanthin, antheraxanthin, $\beta, \beta$-carotene and violaxanthin are also relatively common, forming $10.3,8.0,1.4,0.6$ and $0.5 \%$ of the total mass of carotenoids, respectively. The carotenoids $\alpha$ - and $\beta, \varepsilon$-carotene and their derivatives are present in C. varians tissues at low $(<0.1 \%)$ concentrations (Newsham et al. 2002).

\section{Non-photosynthetic pigments}

Post \& Vesk (1992) isolated the dark pigment present in the tissues of $C$. varians sampled from Clarke Peninsula in Wilkes Land. The pigment was dark under ultraviolet light, had an $R_{\mathrm{f}}$ value of 0.7 and similar mobility on thin layer chromatography plates to anthocyanins. Post \& Vesk

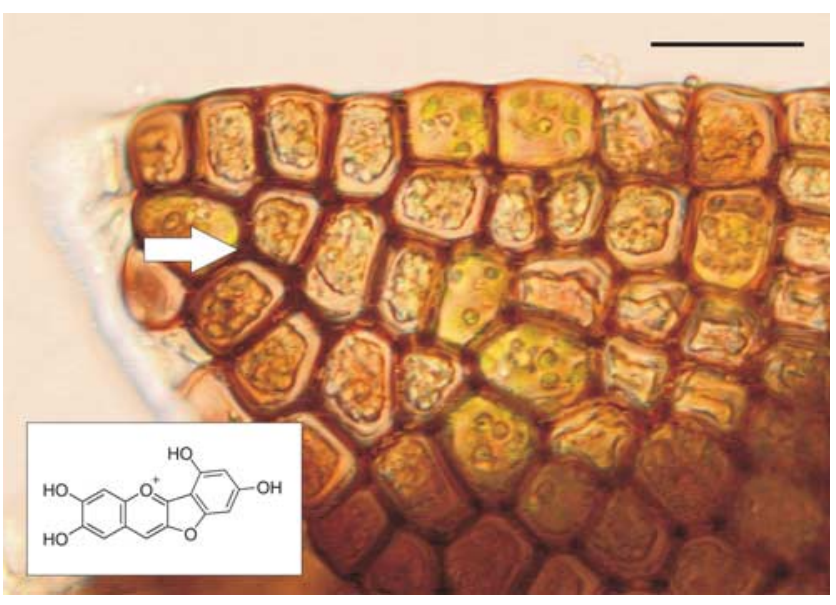

Fig. 7. Micrograph of sun-exposed Cephaloziella varians leaf, showing dark pigmentation in cell walls (arrow). Bar is $20 \mu \mathrm{m}$. Inset shows molecular structure of riccionidin A.

(1992) concluded that it was an anthocyanin-like pigment. The pigment, which is located in the walls of apical cells of sun-exposed leaves (Fig. 7), has a peak of absorption at $495 \mathrm{~nm}$ and minor peaks at 240, 281 and $330 \mathrm{~nm}$. A later study (Snell et al. 2009) showed the pigment, which has a molecular weight of 285 , to be riccionidin $\mathrm{A}\left(\mathrm{C}_{15} \mathrm{H}_{9} \mathrm{O}_{6}\right.$; Fig. 7, inset), a red to purple anthocyanidin found in the cell walls of Rhus javanica L., a vascular plant, and four other liverworts, including Ricciocarpos natans (L.) Corda and Marchantia polymorpha L. (Kunz et al. 1994, Taniguchi et al. 2000). In the absence of an authenticated standard of riccionidin A, comparisons were made between the anthocyanidin extracted from Antarctic $C$. varians and that from north European $R$. natans and M. polymorpha. Snell et al. (2009) found that the molecular masses, spectral profiles and elution times of the pigments from the three hepatics matched, and concluded that riccionidin $\mathrm{A}$ is present in $C$. varians tissues. The anthocyanidin is present at concentrations of $c .2 \mu \mathrm{mol} \mathrm{g}^{-1}$ (dry weight) in sun-exposed plants (Post \& Vesk 1992, Snell et al. 2009).

Other flavonoids are also synthesized by $C$. varians. HPLC analyses have shown there to be at least six, and possibly as many as nine, other acidified methanolextractable flavonoids within the tissues of $C$. varians, none of which have sugar attachments (T. Kokubun, personal communication 2009). In common with riccionidin A, these compounds tend to be localised in apical leaves, which have the highest exposure to solar radiation, but, unlike the anthocyanidin, are present in the cytosol, rather than the cell wall (Snell 2007). The absolute concentrations of these pigments, which vary widely depending on exposure to solar radiation, are currently unknown, but total absorption of acidified-methanol extracts over the UV-B waveband is c. 3-6 mg ${ }^{-1}$ dry weight (Newsham et al. 2002, 2005, Snell et al. 2009). 
Table IV. Carbon, nitrogen, phosphorus and potassium concentrations in C. varians tissues at a range of maritime and sub-Antarctic locations. See Table II for latitudes and longitudes of locations. Data are means of 5-8 replicates \pm SD.

\begin{tabular}{|c|c|c|c|c|}
\hline Location & $\mathrm{C}(\%)^{1}$ & $\mathrm{~N}(\%)^{1}$ & $\mathrm{P}(\%)^{2}$ & $\mathrm{~K}(\%)^{2}$ \\
\hline Foca Point, Signy Island ${ }^{3}$ & $42.82 \pm 0.34$ & $2.30 \pm 0.15$ & $0.024 \pm 0.004$ & $0.165 \pm 0.016$ \\
\hline Factory Bluffs, Signy Island ${ }^{3}$ & $46.48 \pm 0.22$ & $2.26 \pm 0.11$ & $0.025 \pm 0.002$ & $0.136 \pm 0.018$ \\
\hline Rothera Point, Adelaide Island & $47.88 \pm 0.25$ & $1.58 \pm 0.25$ & $0.016 \pm 0.003$ & $0.263 \pm 0.045$ \\
\hline Ablation Valley, Alexander Island & $32.65 \pm 3.18$ & $1.18 \pm 0.15$ & $0.009 \pm 0.001$ & $0.299 \pm 0.030$ \\
\hline Moutonnée Valley, Alexander Island & $30.70 \pm 1.00$ & $1.39 \pm 0.20$ & $0.010 \pm 0.001$ & $0.463 \pm 0.040$ \\
\hline
\end{tabular}

${ }^{1}$ Elementar Vario EL elemental analyser, ${ }^{2}$ Perkin Elmer DRC11 ICP-MS, ${ }^{3}$ South Orkney Islands

\section{Carbohydrates}

Sucrose, trehalose and glucose are reported by Roser et al. (1992) to be the only sugars in the tissues of $C$. varians sampled from Bailey Peninsula. Concentrations of these carbohydrates are $3.3,2.0$ and $1.3 \mathrm{mg} \mathrm{g}^{-1}$ (dry weight), respectively (Roser et al. 1992). A separate study, also on plants from Bailey Peninsula, reports concentrations of sucrose, trehalose, fructose and glucose of 4.3, 1.1, 0.2 and $0.2 \mathrm{mg} \mathrm{g}^{-1}$ (dry weight), respectively (Melick \& Seppelt 1992). Of the polyols, trace levels of arabitol and ribitol (total $0.5 \mathrm{mg} \mathrm{g}^{-1}$ dry weight) and higher levels of mannitol $\left(1.7 \mathrm{mg} \mathrm{g}^{-1}\right.$ dry weight) are present in C. varians tissues sampled from the field. Laboratory-grown plants contain $10.2 \mathrm{mg} \mathrm{g}^{-1}$ (dry weight) of mannitol (Roser et al. 1992).

\section{Tissue chemistry}

Carbon, nitrogen, phosphorus and potassium concentrations of C. varians plants sampled from Bird Island and Signy, Adelaide and Alexander islands in the sub-, northern and southern maritime Antarctic vary between 31 and 48\%, 1.2 and $2.5 \%, 0.009$ and $0.026 \%$ and 0.14 and $0.46 \%$ (dry weight), respectively (Table IV). Reductions occur in the concentrations of the former three elements in C. varians tissues at more southerly locations (Table IV). Bokhorst et al. (2007) report a $\delta^{15} \mathrm{~N}$ value of 11.9 for $C$. varians growing on a soil with a $\delta^{15} \mathrm{~N}$ value of 14.0.

\section{Water relations}

Cephaloziella varians is poikilohydric, and is thus unable to control water loss from its tissues. The water content of tissues is high, owing to the damp environments that the species inhabits, with the substrate below $C$. varians becoming sufficiently waterlogged for decomposition to be inhibited and for methanogenesis to occur (WynnWilliams 1980, 1988, Yarrington \& Wynn-Williams 1985, Davis 1986). Roser et al. (1992), Melick \& Seppelt (1992) and Post \& Vesk (1992) report water contents of 76-80\% (fresh weight) of plants from continental Antarctic locations. Similarly, the water contents of plants at Signy and Adelaide islands are $68 \%$ and $88 \%$ (fresh weight), respectively (Davis 1981, K.K. Newsham, unpublished data). Smith (1972) and Davis (1986) report water contents for substrata under plant communities in which $C$. varians occurs at Signy Island of between 16\% and 1125\% (dry weight). Water evaporation rates for vegetation in which C. varians occurs on Bailey and Clark peninsulas in continental Antarctica are 27 and $38 \mathrm{mg} \mathrm{h}^{-1}$ (Smith 1990).

\section{Response to environment}

\section{Effects of freeze-thaw cycles}

Plants of C. varians subjected to a daily freeze-thaw cycle (between $-15^{\circ} \mathrm{C}$ and $4^{\circ} \mathrm{C}$ ) for 16 days lose $29 \%$ of low molecular weight carbohydrates after leaching with water, compared with plants not subjected to freeze-thaw events, which lose 10\% of carbohydrates (Melick \& Seppelt 1992). This loss is largely accounted for by an increase in sucrose in the leachates. Changes in the freezing points of material subjected to freeze-thaw are not observed, however: after 16 days, those of the control and freeze-thawed material are $-5.4^{\circ} \mathrm{C}$ and $-5.3^{\circ} \mathrm{C}$, respectively (Melick \& Seppelt 1992). These relatively high $\left(>-9^{\circ} \mathrm{C}\right)$ freezing points suggest that C. varians does not avoid freezing, but rather tolerates the freeze-thaw process. The species is able to survive for long periods at temperatures below freezing point: Longton \& Holdgate (1967) and Bednarek-Ochyra et al. (2000) document the growth of $C$. varians after plants had been frozen at up to $-20^{\circ} \mathrm{C}$ for three and 20 years, respectively.

\section{Effects of snowmelt}

Snell et al. (2007) report a rapid increase from 0.18 to 0.45 in the maximum quantum efficiency of photosystem II $\left(F_{\mathrm{v}} / F_{\mathrm{m}}\right)$, and an $88 \%$ increase in the concentrations of chlorophyll $a$ and $b$, during the first $24 \mathrm{~h}$ after $C$. varians emerges from snow. However, there is little evidence of increased concentrations of photoprotective pigments in C. varians as it emerges from melting snow and ice at the end of spring (Snell et al. 2007).

\section{Effects of solar radiation}

Several studies demonstrate that the morphology and pigmentation of $C$. varians responds to solar radiation. In the sun-exposed form, apical leaves tend to be more closely 


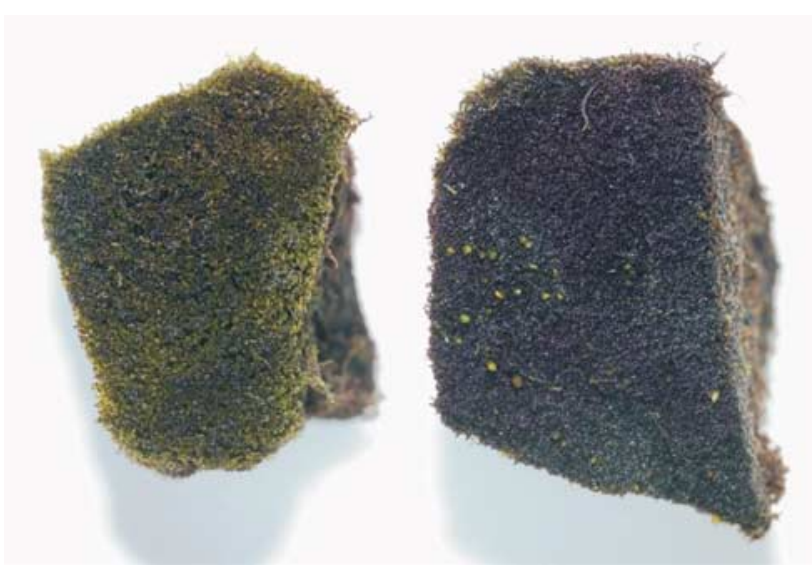

Fig. 8. Mats of Cephaloziella varians exposed to reduced (left) or full (right) solar UV-B radiation for three weeks under Plexiglas screens covered with Mylar polyester or Plexiglas screens only, respectively. The green shoots in the right hand mat are of the moss Bryum pseudotriquetrum. Reproduced from Snell (2007).

spaced than in the shade form, and overlap each other slightly (Post \& Vesk 1992). The shade form of the species has elongated internodes and may have smaller leaves. Sun-exposed leaves have thick cell walls, particularly on the abaxial surface.

Post \& Vesk (1992) report that apical leaves of C. varians from sun-exposed habitats accumulate higher concentrations of an anthocyanin-like pigment (riccionidin A; see nonphotosynthetic pigments, above) than those from shaded habitats. They also show that sun-exposed plants have lower concentrations of chlorophyll and higher carotenoid/ chlorophyll ratios than shade-adapted plants. The accumulation of riccionidin $\mathrm{A}$ in apical leaves is owing to exposure to solar UV-B radiation (Newsham et al. 2005): the pigment is lost within approximately three weeks when UV-B radiation exposure is reduced to $30 \%$ of that in sunlight, achieved by placing Mylar polyester screens over plants in the natural environment (Fig. 8). If the species is then exposed to an abrupt increase in solar UV-B exposure by removing the screens, the anthocyanidin is resynthesized within $48 \mathrm{~h}$ at a mean air temperature of $0.9^{\circ} \mathrm{C}$ (Snell et al. 2009), with a visible darkening of its tissues during this period. Snell et al. (2009) estimate that a minimum of $1.85 \%$ of the carbon fixed in photosynthesis is used to synthesize riccionidin A during this period.

Cephaloziella varians displays rapid responses to changes in UV-B exposure arising from ozone depletion, with concentrations of UV-B screening pigments (putative colourless flavonoids) tracking solar UV-B irradiances, implying that plants respond rapidly (within $24 \mathrm{~h}$ ) to UV-B exposure (Newsham et al. 2002). Concentrations of carotenoids, notably neoxanthin, violaxanthin and lutein, are also positively associated with the flux of UV-B radiation in sunlight (Newsham et al. 2002).

\section{Associated organisms}

Bryophytes and vascular plants

Cephaloziella varians is frequently associated with many other bryophyte species in the Antarctic (Ochyra et al. 2008). It is a common member of the short moss cushion and turf sub-formation, the tall moss turf sub-formation and the bryophyte carpet and mat sub-formation (Smith 1996). It also occurs amongst the two native Antarctic vascular plant species, Deschampsia antarctica Desv. and Colobanthus quitensis (Kunth) Bartl., and in the grass and cushion chamaephyte sub-formation, usually in well-drained habitats (Ochyra \& Váňa 1989a). Although C. varians is often sparsely distributed amongst other bryophytes, it can form almost pure stands of up to $2-3 \mathrm{~m}^{2}$ in area and attains covers in mixed bryophyte communities of $13 \%$ at Signy Island (WynnWilliams 1980, Davis 1981) and 65\% on Bailey Peninsula (Smith 1990).

\section{Invertebrates}

Many invertebrates occur amongst the shoots of $C$. varians and in the substratum beneath them. Cryptopygus antarcticus Willem, a widespread maritime Antarctic collembolan, is frequent in mats of $C$. varians at Signy Island and at Rothera Point. At the latter site, unidentified bdelloid rotifers, the nematodes Aphelenchoides haguei Maslen, Coomansus gerlachei (de Man) Jairajpuri \& Kahn, Eudorylaimus pseudocarteri Loof, E. coniceps Loof, Plectus antarcticus de Man, P. belgicae de Man and Rhyssocolpus paradoxus (Loof) Andrassy, and the tardigrades Diphascon and Echiniscus spp., Hypsibius cfr. dujardini Doyère and Macrobiotus furciger Murray, are frequently found in the substratum beneath C. varians (Newsham et al. 2006, N.R. Maslen, personal communication 2009). As yet, there is little to suggest that any of these invertebrates are specific to substrata under C. varians.

\section{Fungi}

Microscopic examination of $C$. varians from the Antarctic almost invariably reveals fungal hyphae ramifying through the shoot. Williams et al. (1994) were the first to report the presence of fungi in the tissues of the species. They documented dark septate hyphae and rudimentary coils, resembling those formed by ericoid mycorrhizal fungi in the hair roots of ericaceous plants, in the rhizoids of C. varians from Bailey Peninsula and Botany Bay, both in the continental Antarctic. Subsequently, Chambers et al. (1999) sequenced the Internal Transcribed Spacer (ITS) region of a fungus isolated by Williams et al. (1994) from plants on Bailey Peninsula and found that it displayed $<2.1 \%$ divergence from that of the type culture of Rhizoscyphus ericae (Read) Zhuang \& Korf., a widespread mycorrhizal fungus in heathland and boreal ecosystems (Smith \& Read 2008). 


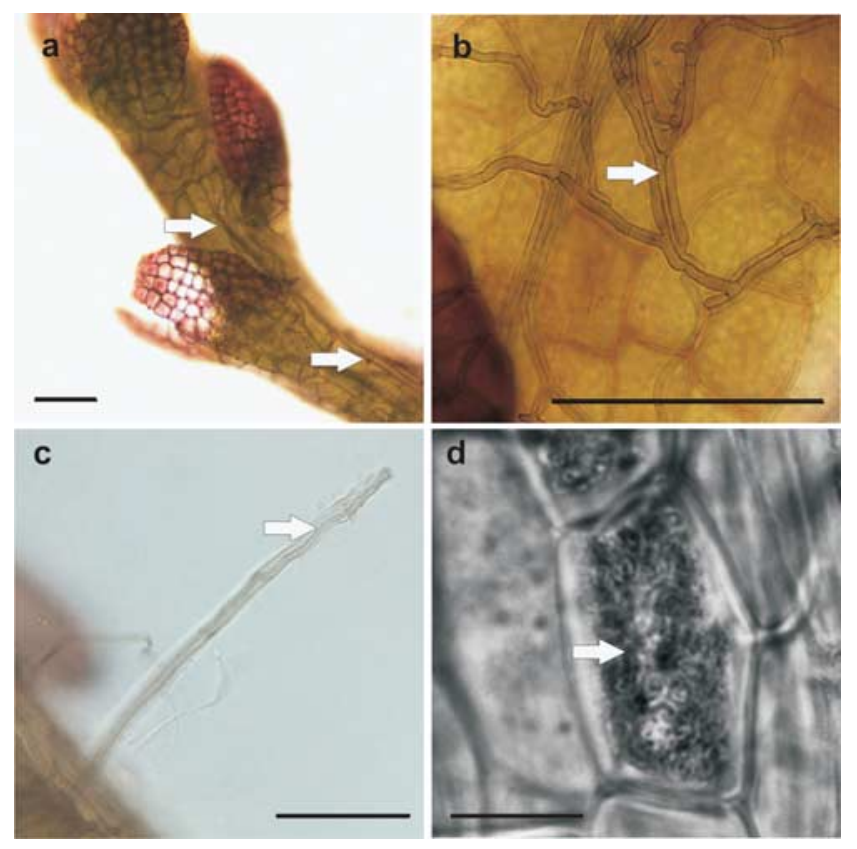

Fig. 9. Micrographs of a. fungal hyphae in Cephaloziella varians shoot (arrows), b. hyphae forming strands on shoot surface (arrow), c. hypha colonizing a rhizoid (arrow), and d. hyphal coil in axial cell (arrow). Bars in a-d are 80, 50, 25 and $10 \mu \mathrm{m}$, respectively. Reproduced, with permission from Wiley-Blackwell, from Upson et al. (2007).

Further studies revealed that $R$. ericae is abundant in the tissues of C. varians along a $1875 \mathrm{~km}$ transect from Bird Island in the sub-Antarctic, through to Coronation, Lynch and Signy islands in the South Orkneys, King George and Livingston Islands in the South Shetlands, and Adelaide and Alexander islands, off the south-western Antarctic Peninsula (Upson et al. 2007). Analyses of ITS1-5.8S-ITS2 and $28 \mathrm{~S}$ large subunit sequences indicated that isolates are 98-99\% similar to those of $R$. ericae from North America, Australia and Europe (Upson et al. 2007). Fungal hyphae ramify through the tissues of the plant almost to the apical meristem, forming strands of hyphae on the shoot surface, and also frequently colonize rhizoids (Fig. 9a-c). Hyphal coils, similar to those observed by Williams et al. (1994) in plants from Bailey Peninsula, are also formed by $R$. ericae in the axial cells of axenically-grown plants (Fig. 9d).

Although $R$. ericae is widespread in the rhizoids of $C$. varians in the maritime and sub-Antarctic, other apparently non-pathogenic fungi also colonize the tissues of the plant. Sequencing of fungal $18 \mathrm{~S}$ small subunit genes amplified directly from $C$. varians from Adelaide Island reveals a diverse fungal community, including sequences conspecific with a large group of fungi nested within the Chaetothyriales, and those similar to Rhizoscyphus spp. and Phialocephala fortinii Wang \& Wilcox (Jumpponen et al. 2003). Mats of $C$. varians from the Terra Firma Islands in southern Marguerite Bay, off the south-western Antarctic
Peninsula, yield nematode-trapping ring fungi (Duddington et al. 1973). Geothermally-heated soils under C. varians on Mount Melbourne also yield Mucor, Penicillium and Cryptococcus spp. (Broady et al. 1987).

\section{Algae, cyanobacteria and protozoa}

The microalga Stichococcus bacillaris Nägeli is frequently isolated from $C$. varians mats at Rothera Point and Signy Island, and the foliose alga Prasiola crispa (Lightf.) Kütz. is also commonly found growing amongst mats of $C$. varians at these locations. Broady et al. (1987) report the alga Chlorella cf. reniformis Watan., the testate amoeba Corythion dubium Taranek., and the cyanobacteria Gloeocapsa magma (Bréb.) Holl., Tolypothrix bouteillei (Bréb. \& Desm.) Lemm. and Stigonema ocellatum Thuret, to be present with $C$. varians in geothermally-heated soils on Mount Melbourne.

\section{Disease}

No specific reports of any pathogens on C. varians exist in the literature. However, rings formed by Thyronectria antarctica occur in mats of $C$. varians in the northern maritime Antarctic (R.I.L. Smith, personal communication 2009). A species of Pythium, which bears phylogenetic affinities to snow moulds and causes dieback symptoms in Deschampsia antarctica (Bridge et al. 2008), is present in mats of $C$. varians at Adelaide Island, as is Phoma herbarum Westend (Hughes et al. 2003), a globally-distributed weak fungal pathogen.

\section{Adaptations of $C$. varians to the Antarctic natural environment}

In their review of the phytogeography of Antarctic hepatics, Bednarek-Ochyra et al. (2000) note that (the) distribution pattern of liverworts in the maritime Antarctic implies that particular species differ markedly in their tolerance of severe environmental conditions, and there are only a very few which have adapted physiologically to very low temperatures and long periods of continual daylight. Cephaloziella varians is clearly one such species: from the literature reviewed above, it is evident that it tolerates a range of stresses in the Antarctic natural environment. The foremost of these are the wide diurnal $\left(20-30^{\circ} \mathrm{C}\right)$ and annual $\left(50-60^{\circ} \mathrm{C}\right)$ fluctuations in temperature to which the species is exposed, the absence of solar radiation for several months each year, and exposure to high irradiances of solar radiation, including damaging shortwave UV-B radiation, during the brief growing season.

What adaptations does C. varians possess in order for it to survive these hostile conditions? Although the photosynthesis of the species displays rapid responses to snowmelt, enabling it to maximize carbon acquisition during the short growing season (Snell et al. 2007), it seems unlikely that the ability of the species to fix carbon is substantially greater than that of other bryophytes in 
Antarctica. Assuming a photosynthetic quotient of 1 for Antarctic bryophytes (Longton 1974), the estimated carbon fixation rates of the species (up to 87 and $57 \mu \mathrm{mol} \mathrm{CO} \mathrm{CO}_{2} \mathrm{~g}^{-1}$ dry weight $\mathrm{h}^{-1}$ at $10^{\circ} \mathrm{C}$ for the sun-exposed and shade forms; Snell et al. 2009) is similar to that of other hydric species of Antarctic mosses and liverworts $(33-83 \mu \mathrm{mol}$ $\mathrm{CO}_{2} \mathrm{~g}^{-1}$ dry weight $\mathrm{h}^{-1}$ at $10^{\circ} \mathrm{C}$; Davey \& Rothery 1997). The concentrations of chlorophylls in its tissues (0.2-0.4 $\mathrm{mg} \mathrm{g}^{-1}$ fresh weight) are also similar to those of other Antarctic mosses $\left(0.3-0.9 \mathrm{mg} \mathrm{g}^{-1}\right.$ fresh weight; Rastorfer 1972, Roser et al. 1992).

Although the concentrations of photosynthetic pigments in the tissues of $C$. varians apparently do not differ from those of other Antarctic bryophytes, it is probable that the flavonoid pigments synthesized by the species play a significant role in its survival in the natural environment. Of note is the presence of riccionidin A in sun-exposed apical leaves: this anthocyanidin enables efficient heat absorption by $C$. varians tissues, increasing their temperature by several degrees relative to associated moss species. The shading of chloroplasts by this flavonoid most probably also reduces photoinhibition at high irradiances, with the oxygen evolution of shade-adapted plants, which lack the pigment, saturating at 200-400 $\mu$ mol photons $\mathrm{m}^{-2} \mathrm{~s}^{-1}$, but that of sun-exposed plants, which possess the pigment, not becoming saturated at irradiances of $<1090 \mu \mathrm{mol}$ photons $\mathrm{m}^{-2} \mathrm{~s}^{-1}$ (Post \& Vesk 1992, Snell et al. 2009). Two other Antarctic hepatics, Lophozia excisa and Barbilophozia hatcheri, which extend to c. $68^{\circ} \mathrm{S}$ on the south-western Antarctic Peninsula, also synthesize dark pigments in apical leaves (Bednarek-Ochyra et al. 2000), which might similarly contribute to tolerance of high solar radiation exposure in the southern maritime Antarctic. Tolerance of high irradiance, although not ascribed to dark pigmentation, has been put forward as a reason for the success of Deschampsia antarctica and Colobanthus quitensis in the Antarctic natural environment (Smith 2003). Riccionidin A and other colourless flavonoids, which most probably scavenge free radicals during periods of high solar radiation exposure, are aglycones, and can thus be synthesized at a low metabolic cost to C. varians (Snell et al. 2009). Furthermore, the colourless flavonoids synthesized by the species appear to protect photosystem II from rapid changes in UV-B exposure during periods of ozone depletion in the stratosphere over the Antarctic (Newsham et al. 2002).

Another key adaptation of $C$. varians appears to be its association with the mycorrhizal symbiont Rhizoscyphus ericae. This fungus, which facilitates the uptake of nitrogen by the roots of ericaceous plants in acidic, nutrient-poor soils at lower latitudes (Smith \& Read 2008), has a widespread and consistent association with $C$. varians throughout the maritime Antarctic (Chambers et al. 1999, Upson et al. 2007). At present, the nature of any possible benefit to $C$. varians from $R$. ericae is unclear, but the formation in the cells of axenically-grown plants of hyphal coils, which maximise the surface area of contact between symbionts in ericoid mycorrhizas (Smith \& Read 2008), is suggestive of active nutrient exchange between the liverwort and the fungus (Upson et al. 2007). However, with the exception of nitrate at some locations, inorganic nutrient availability in soils on which $C$. varians occurs in the Antarctic is within the range of that considered to be optimal for plant growth at lower latitudes (Holdgate et al. 1967, Allen 1989). Nutritional benefits of $R$. ericae colonization to $C$. varians might hence not be expected under such conditions of optimal inorganic nutrient supply. Resynthesis experiments under axenic conditions are hence required to resolve the question of whether $R$. ericae enhances the flow of nitrogen into the tissues of $C$. varians or not, and whether the liverwort benefits from its association with the fungus in this way in the natural environment.

A further adaptation enabling the survival of $C$. varians in the Antarctic terrestrial biome is the presence of cryoprotectants, notably sucrose, mannitol and trehalose, in its tissues. The last is an effective cryoprotectant that is considered to confer desiccation tolerance and osmotic protection on a range of Antarctic plants and animals by stabilizing cell membranes during dehydration (Montiel 2000). The presence of cryoprotectants in the tissues of C. varians might explain the survival of the liverwort for several years at temperatures below freezing point (Longton \& Holdgate 1967, Bednarek-Ochyra et al. 2000) and the ability of the species to remain frozen in a dehydrated state during winter in the natural environment. Previous studies suggest that polyols are synthesized by leafy liverworts, and not by their associated fungi (Christie et al. 1985). However, the presence in $C$. varians of mannitol, a sugar alcohol frequently used as a fungal storage compound, at 60 times greater concentrations than in those of associated mosses, and at similar concentrations to those in lichens, suggests that fungi present in $C$. varians may benefit the liverwort by synthesizing polyols in its tissues (Roser et al. 1992).

Further comparative studies between $C$. varians and other Antarctic hepatics are required to determine the precise reasons for the success of the species in the high maritime and continental Antarctic. At present, however, it seems likely that the presence in $C$. varians of riccionidin A, colourless flavonoids, cryoprotectants and fungal symbionts account, at least in part, for the remarkable geographical range of the hepatic and its tolerance of environmental stresses in the Antarctic terrestrial biome.

\section{Acknowledgements}

Ron Lewis Smith and the late David Wynn-Williams initiated my interest in C. varians. The former, along with two anonymous referees, supplied extensive and helpful comments on the manuscript. Peter Fretwell and Peter Bucktrout kindly assisted with the preparation of the figures and Tetsuo Kokubun, Rolf Maslen, Pete Convey, Rebecca Upson, Katherine Snell, Helen Peat and Richard Hall 
provided useful data, comments and discussions. The Analytical Chemistry Service at CEH Lancaster provided the chemical data shown in Table IV. Funding from the UK Natural Environment Research Council, in part through the British Antarctic Survey's Long Term Monitoring and Survey programme, is gratefully acknowledged.

\section{References}

AlLen, S.E. 1989. Chemical analysis of ecological materials. Oxford: Blackwell Scientific Publications, 368 pp.

Bednarek-Ochyra, H., VÁŇa, J., Ochyra, J.V.R. \& Smith, R.I.L. 2000. The liverwort flora of Antarctica. Cracow: Polish Academy of Sciences, Institute of Botany, $236 \mathrm{pp}$.

Bokhorst, S., Huiskes, A., Convey, P. \& Aerts, R. 2007. External nutrient inputs into terrestrial ecosystems of the Falkland Islands and the maritime Antarctic region. Polar Biology, 30, 1315-1321.

Bridge, P.D., Newsham, K.K. \& Denton, G.J. 2008. Snow mould caused by a Pythium sp.: a potential vascular plant pathogen in the maritime Antarctic. Plant Pathology, 57, 1066-1072.

Broady, P., Given, D., Greenfield, L. \& Thompson, K. 1987. The biota and environment of fumaroles on Mt Melbourne, Northern Victoria Land. Polar Biology, 7, 97-113.

Chambers, S.M., Williams, P.G., Seppelt, R.D. \& Cairney, J.W.G. 1999. Molecular identification of Hymenocyphus sp. from rhizoids of the leafy liverwort Cephaloziella exiliflora in Australia and Antarctica. Mycological Research, 103, 286-288.

Christie, A., Pocock, K., Lewis, D.H. \& Duckett, J.G. 1985. A comparison between the carbohydrates of axenically cultured hepatics and of those collected from the field. Journal of Bryology, 13, 417-422.

Convey, P. \& Smith, R.I.L. 2006. Geothermal bryophyte habitats in the South Sandwich Islands, maritime Antarctic. Journal of Vegetation Science, 17, 529-538.

Convey, P., Smith, R.I.L., Hodgson, D.A. \& Peat, H.J. 2000. The flora of the South Sandwich Islands, with particular reference to the influence of geothermal heating. Journal of Biogeography, 27, 1279-1295.

DAVEY, M.C. \& RoTHERY, P. 1997. Interspecific variation in respiratory and photosynthetic parameters in Antarctic bryophytes. New Phytologist, 137, 231-240.

DAvis, E.C. 2004. A molecular phylogeny of leafy liverworts (Jungermanniidae: Marchantiophyta). Monographs in Systematic Botany, 98, 61-86.

DAvis, R.C. 1981. Structure and function of two Antarctic terrestrial moss communities. Ecological Monographs, 51, 125-143.

DAvIs, R.C. 1986. Environmental factors influencing decomposition rates in two Antarctic moss communities. Polar Biology, 5, 95-103.

Duddington, C.L., Wyborn, C.H.E. \& Smith, R.I.L. 1973. Predacious fungi from the Antarctic. British Antarctic Survey Bulletin, No. 35, $87-90$.

Forrest, L.L., Davis, E.C., Long, D.G., Crandall-Stotler, B.J., Clark, A. \& Hollingsworth, M.L. 2006. Unraveling the evolutionary history of the liverworts (Marchantiophyta): multiple taxa, genomes and analyses. The Bryologist, 109, 303-334.

Fulford, M.H. 1976. Manual of the leafy Hepaticae of Latin America. Part IV. Memoirs of the New York Botanical Garden, 11, 393-535.

GotTsche, C.M. 1890. Die Lebermoose Süd-Georgiens. In Neumayer, G., ed. Die Internationale Polarforschung 1882-83. Die Deutschen Expeditionen und ihre Ergebnisse, 2. Berlin: Asher, 449-454.

Grolle, R. 1972. The hepatics of the South Sandwich Islands and South Georgia. British Antarctic Survey Bulletin, No. 28, 83-95.

Holdgate, M.W., Allen, S.E. \& Chambers, M.J.G. 1967. A preliminary investigation of the soils of Signy Island, South Orkney Islands. British Antarctic Survey Bulletin, No. 12, 53-71.
Hughes, K.A., Lawley, B. \& Newsham, K.K. 2003. Solar radiation inhibits the growth of Antarctic terrestrial fungi. Applied and Environmental Microbiology, 69, 1488-1491.

Jumpronen, A., Newsham, K.K. \& Neises, D.J. 2003. Filamentous ascomycetes inhabiting the rhizoid environment of the liverwort Cephaloziella varians in Antarctica as assessed by direct PCR and cloning. Mycologia, 95, 457-466.

Konstantinova, N.A. \& Potemkin, A.D. 1996. Liverworts of the Russian Arctic: an annotated check-list and bibliography. Arctoa, 6, 125-150.

Kunz, S., Burkhardt, G. \& Becker, H. 1994. Riccionidins A and B, anthocyanidins from the cell walls of the liverwort Ricciocarpos natans. Phytochemistry, 35, 233-235.

Longton, R.E. 1974. Microclimate and biomass in communities of the Bryum association on Ross Island, continental Antarctica. The Bryologist, 77, 109-127.

Longton, R.E. \& Holdgate, M.W. 1967. Temperature relationships of Antarctic vegetation. Philosophical Transactions of the Royal Society of London, B252, 237-250.

Longton, R.E. \& Holdgate, M.W. 1979. The South Sandwich Islands. 4. Botany. British Antarctic Survey Science Report, No. 94, 53 pp.

Melick, D.R. \& Seppelt, R.D. 1992. Loss of soluble carbohydrates and changes in freezing point of Antarctic bryophytes after leaching and repeated freeze-thaw cycles. Antarctic Science, 4, 399-404.

MonTIEL, P.O. 2000. Soluble carbohydrates (trehalose in particular) and cryoprotection in polar biota. Cryoletters, 21, 83-90.

Newsham, K.K., Maslen, N.R. \& McInnes, S.J. 2006. Survival of Antarctic soil metazoans at $-80^{\circ} \mathrm{C}$ for six years. Cryoletters, 27, 291-294.

Newsham, K.K., Geissler, P.A., Nicolson, M.J., Peat, H.J. \& Lewis-Smith, R.I. 2005. Sequential reduction of UV-B radiation in the field alters the pigmentation of an Antarctic leafy liverwort. Environmental and Experimental Botany, 54, 22-32.

Newsham, K.K., Hodgson, D.A., Murray, A.W.A., Peat, H.J. \& Sмith, R.I.L. 2002. Response of two Antarctic bryophytes to stratospheric ozone depletion. Global Change Biology, 8, 972-983.

Newton, M.E. 1980. Chromosome studies in some Antarctic and subAntarctic bryophytes. British Antarctic Survey Bulletin, No. 50, 77-86.

OCHYRA, R. \& VÁŇA, J. 1989a. The hepatics of King George Island, South Shetland Islands, Antarctica, with particular reference to the Admiralty Bay region. Polish Polar Research, 10, 183-210.

OCHYRA, R. \& VÁŇA, J. 1989b. The hepatics reported from the Antarctic and an outline of their phytogeography. Polish Polar Research, 10, 211-229.

Ochyra, R., Lewis-Smith, R.I. \& Bednarek-Ochyra, H. 2008. The illustrated moss flora of Antarctica. Cambridge: Cambridge University Press, $685 \mathrm{pp}$.

Ochyra, R., Przywara, L. \& Kuta, E. 1982. Karyological studies on some Antarctic liverworts. Journal of Bryology, 12, 259-263.

Post, A. \& Vesk, M. 1992. Photosynthesis, pigments and chloroplast ultrastructure of an Antarctic liverwort from sun-exposed and shaded sites. Canadian Journal of Botany, 70, 2259-2264.

RAstoRfer, J.R. 1972. Comparative physiology of four West Antarctic mosses. Antarctic Research Series, 20, 143-161.

Roser, D.J., Melick, D.R., Ling, H.U. \& Seppelt, R.D. 1992. Polyol and sugar content of terrestrial plants from continental Antarctica. Antarctic Science, 4, 413-420.

SchlJakov, R.N. 1979. Pechenochnye mkhi severa SSSR. Vyp. 2. Pechenochniki: Gerbertovye - Geokaliksovye. Leningrad: Leningradskoe Otdelenie, $191 \mathrm{pp}$.

Schuster, R.M. 1980. New combinations and new taxa of Hepaticae, I. Phytologia, 45, 415-437.

Schuster, R.M. \& Damsholt, K. 1974. The Hepaticae of West Greenland from ca. $66^{\circ} \mathrm{N}$ to $72^{\circ} \mathrm{N}$. Meddelelser om Grønland, 199, 1-373.

Seppelt, R.D. 1983. Cephaloziella exiliflora (Tayl.) Steph. from the Windmill Islands, continental Antarctica. Lindbergia, 9, 27-28. 
Seppelt, R.D. \& Green, T.G.A. 1998. A bryophyte flora for Southern Victoria Land, Antarctica. New Zealand Journal of Botany, 36, 617-635.

SмIтH, R.I.L. 1972. Vegetation of the South Orkney Islands with particular reference to Signy Island. British Antarctic Survey Scientific Reports, No. 68,129 pp.

Sмith, R.I.L. 1984. Terrestrial plant biology of the sub-Antarctic and Antarctic. In Laws, R.M., ed. Antarctic ecology, vol. 1. London: Academic Press, 61-162.

Sмith, R.I.L. 1990. Plant community dynamics in Wilkes Land, Antarctica. Proceedings of the National Institute of Polar Research Symposium on Polar Biology, 3, 229-244.

Sмith, R.I.L. 1996. Terrestrial and freshwater biotic components of the western Antarctic Peninsula. Antarctic Research Series, 70, 15-59.

SмITH, R.I.L. 2003. The enigma of Colobanthus quitensis and Deschampsia antarctica in Antarctica. In Huiskes, A.H.L., Gieskes, W.C., Rozema, J., Schorno, R.M.L., van der VIES, S.M. \& WolfF, W.J., eds. Antarctic biology in a global context. Leiden: Backhuys Publishers, 234-239.

SмITH, R.I.L. 2005. The thermophilic bryoflora of Deception Island: unique plant communities as a criterion for designating an Antarctic Specially Protected Area. Antarctic Science, 17, 17-25.

Smith, R.I.L. 2007. Liverworts. In RiffenbuRGH, B., ed. Encyclopaedia of the Antarctic. London: Routledge, 596-597.

SMith, R.I.L. \& Convey, P. 2002. Enhanced sexual reproduction in bryophytes at high latitudes in the maritime Antarctic. Journal of Bryology, 24, 107-117.

Smith, S.E. \& Read, D.J. 2008. Mycorrhizal symbiosis, 3rd ed. London: Academic Press, 605 pp.

SNeLL, K.R.S. 2007. Photoprotective pigments in Cephaloziella varians: investigating responses to climate change. MPhil thesis, Open University, 224 pp. [Unpublished.].

SNell, K.R.S., Convey, P. \& Newsham, K.K. 2007. Metabolic recovery of the Antarctic liverwort Cephaloziella varians during spring snowmelt. Polar Biology, 30, 1115-1122.

Snell, K.R.S., Kokubun, T., Griffiths, H., Convey, P., Hodgson, D.A. \& Newsham, K.K. 2009. Quantifying the metabolic cost to an
Antarctic liverwort of responding to an abrupt increase in UV-B radiation exposure. Global Change Biology, 15, 2563-2573.

SöDerström, L. 1995. Preliminary distribution maps of bryophytes in norden. Vol 1. Hepaticae and Anthocerotae. Trondheim: Mossornas Vänner, $51 \mathrm{pp}$.

Stephani, F. 1901. Hepatiques. In Résultats du Voyage du S.Y. Belgica en 1897-1898-1899 sous le Commandement de A. de Gerlache de Gomery. Expédition Antarctique Belge. Rapports Scientifiques. Antwerp: J.-E. Buschmann, $6 \mathrm{pp}$.

Stephani, F. 1905. Hepaticae gesammelt von C. Skottsberg während der Schwedischen südpolarexpedition 1901-1903. In Wissenschaftliche Ergebnisse Schwedischen Südpolar-Expedition 1901-1903 unter Leitung von Dr. Otto Nordenskjöld 4 (1). Stockholm: Lithographisches Institut des Generalstabs, 11 pp.

Taniguchi, S., Yazaki, K., Yabu-uchi, R., Kawakami, K., Ito, H., Hatano, T. \& Yoshida, T. 2000. Galloylglucoses and riccionidin A in Rhus javanica adventitious root cultures. Phytochemistry, 53, 357-363.

Upson, R., Read, D.J. \& Newsham, K.K. 2007. Widespread association between the ericoid mycorrhizal fungus Rhizoscyphus ericae and a leafy liverwort in the maritime and sub-Antarctic. New Phytologist, 176, 460-471.

Williams, P.G., Roser, D.J. \& Seppelt, R.D. 1994. Mycorrhizas of hepatics in continental Antarctica. Mycological Research, 98, 34-36.

Wynn-WiLliams, D.D. 1980. Seasonal fluctuations in microbial activity in Antarctic moss peat. Biological Journal of the Linnean Society, 14, $11-28$.

Wynn-Williams, D.D. 1988. Cotton strip decomposition in relation to environmental factors in the maritime Antarctic. In HARRISON, A.F., Latter, P.M. \& Walton, D.W.H., eds. Cotton strip assay: an index of decomposition in soils. Grange-over-Sands: Institute of Terrestrial Ecology, 126-133.

YARRINGTON, M.R. \& WYNN-WILLIAMS, D.D. 1985. Methanogenesis and the anaerobic microbiology of a wet moss community at Signy Island. In Siegfried, W.R., Condy P.R. \& Laws, R.M., eds. Antarctic nutrient cycles and food webs. Berlin: Springer, 229-233. 